\title{
THE BENGAL SCENE
}

Opium ... The Arab afyūn is sometimes corruptly called afin, of which afinn, "imbecile". is a popular etymology. Similarly the Bengalees derive it from afi-heno, "serpent-home".

Patna ... is the most celebrated place in the world for the cultivation of opium. Besides what is carried into the inland parts, there are annually 3 or 4000 chests exported, each weighing $300 \mathrm{lbs} . .$.

Guillaume Raynal (1777)

The VOC's participation in the Indian trade started with a trading post at Petapuli (Nizampatnam) in north Coromandel in 16o6. K. Chaudhuri made an interesting general remark about companies like the VOC:

... specific examples and the general evidence from the records of the trading companies prove conclusively that in the main port towns of India, the Red Sea, or China, the organisation of the market in the seventeenth and eighteenth centuries followed lines that were to be found in contemporaneous Europe. ${ }^{2}$

An amendment is necessary here: this conclusion does not match the very violent ingress of the Europeans and the reactions of the indigenous economic and political interests to their repression. That would have been an exceptional situation in the European trade networks. Until the 17 th-century the usual reasons for starting a war in Europe were of a religious or dynastic-political nature. Thereafter, both remain necessary, because pure trading interests are never favored by war; the combination of these three leads to "monopoly wars", which is nothing but the dynastic motive to become the sole ruler in a market. The result is still the elimination of a market and, therefore, of the basis of every trade (see further below).

\footnotetext{
1 Quoted in the Hobson-Jobson, p. 641, 642.

2 K. N. Chaudhuri (1978), p. 145.
} 
This makes Chaudhuri's discussion of Max Weber's thought about types of merchants and the availability of 'capitalistic profit-making enterprises ... [which] ... operate in markets that may be entirely free or subject to substantive regulations' ${ }^{3}$ more or less suspect. In their continuous attack the English could be included in the category of these private market-oriented, capitalist merchant-pirates only in the first phase of their arrival in the realm. The same is true for the Dutch voyages in the pre-VOC period, the time of the so-called "Voor-Compagnieën" ("PreCompanies").

The EIC, however, was like a state with an army and monopoly claims. It was first indirectly and later directly supported by the British state (London and the king). This was also the case with the Portuguese, the Spaniards, the French and the VOC, whatever differences there were in the degree of state involvement. "Monopoly" is the catchword in all these state-private ventures, and this remained the main characteristic of Western imperialism and colonialism until far into the 2oth-century.

For the historical, economic and other interpretations of the Western collision with "Asia", the following aspect is of overriding importance, about which no misunderstanding should exist: it is much too easy to say that an "open" and "free" Western capitalism conquered the "traditionbound" or "closed" East.

With the Battle of Plassey in 1757, a new period started in the north and east of India, because it was seen as the start of the British Empire. It was sanctioned more or less by the grant of the diwani of Bengal to the EIC, which is the right of rulers and a state to collect taxes. A fundamental British reconstruction of the north and east of India included the opium regime.

The cultivation of poppies remained in the hands of the peasants, but 'the entire crop belonged to the company's government, and private sales were forbidden'. ${ }^{4}$ Indian entrepreneurs and merchants who had been active in the opium business did not give it up. They could continue only 'by grace of the enormous bribes they paid to the company servants' ${ }^{5}$ Already in 1786 the English obtained the Benares opium (and saltpeter) monopoly, and the powerful merchant magnates were seriously weakened or eliminated (what happened with the Malwa opium center around Bombay is told in ch. 7).

\footnotetext{
3 Idem, p. 146.

4 K. Chatterjee, p. 116.

5 C. Trocki (1999a), p. 45.
} 
The reverse side of this coin was that English private fortunes were now being made in Bengal, Bihar or Patna. People like George Vansittart, Ewan Law or William Young made handsome profits in the 1770 s as the plans for the opium conquest of China were gradually formed. One development went even further. After the Battle of Plassey, the British became the territorial ruler (1772) and now this

elevation to the status of ruler compelled it to attend to problems that either it had ignored or had fallen outside the scope of its authority prior to 1765 . The regulation of taxes and dues, charged upon trade in transit, was one of the first areas to draw the company's attention. ${ }^{6}$

Indeed, this often led to two conflicting interests. The common aim was to exploit the Indians, eventually with the help of Indians (compradors). At the same time, however, the trade interest had to consider the state interest as parasitical: if it could not squeeze enough from the Indians, it had to compensate its costs through the trade interest. This is another definition of the ambiguous position of Warren Hastings (see ch. 6).

The English used their colonial whip to enhance their authority, tease their competitors and increase production. Chatterjee writes about this period:

The intensified English effort to penetrate the opium business had both a corporate and a private dimension. Through the 1760 s, increasingly aggressive British private traders, together with gomastahs employed for the purpose of buying opium for the English company's corporate business, unleashed a regime of tyranny and oppression over the opium growers. Ramchand Pandit's memoir described vividly how the English "gentlemen", as he described them, compelled the opium growers to accept low prices by placing peons over them. ${ }^{7}$

There were, however, also harsh conflicts among the European opium buyers. In the summer of 1767 French gomastahs decorated poppy fields around Bihar with flags claiming a right to all the opium produced on those lands. The EIC retaliated by forbidding the peasants to sell opium to the French:

6 K. Chatterjee, p. 129.

7 Idem, p. 114. Middlemen or agents called gomastahs operate between the producers and the great merchants or bankers as the latter's representative; they are mostly engaged at monthly wages. A peon is a person with little authority, often assigned to do unskilled or drudgerous tasks; an underling. In this case, it must be someone, who knows how to handle a club or is doing 'police service' (Hobson-Jobson). 
French gomastahs were imprisoned and French aurungs were plundered of all opium and other goods stored there. The punitive measures against the French company spilled over into the French textile enterprise and English gomastahs destroyed textiles being woven for the French. ${ }^{8}$

Around 1790 after many reorganizations, the revenue administration of the English concerned mainly the land tax, the salt and the opium monopolies, and the customs and excise fees (the sair). The opium revenue had been managed ever since 1773 by a contract with Indian merchants, who paid a royalty to the EIC. A few years later the contract was awarded to the highest bidder on a four-years' agreement. The EIC servants had a right of inquiry 'to prevent the oppression of the opium peasants'; the best basis for bribes. The consequences of this rather corrupt constellation for production and trade are sketched in some detail in chapter 6 .

There was a specific reason for the harsh regime imposed on poppy growers. No goods other than saltpeter and opium were ever made subject to formal control. Not because both were cultivated exclusively in Bihar, but because both were military strategic goods: the first as a raw material for gunpowder; on the second supported the officials' main governmental and personal profit-making method, while the bullion and tea trade came to depend on opium. ${ }^{9}$ For all these reasons the opium history of India in the 19th-century was largely a British government affair.

In the previous chapter, however, it was shown how important the opium trade from Bengal to the Malabar coast was already in the 17th-century when English merchants were not yet very active. In this "Dutch century" the centrality of the Bengal-Bihar (Patna, Benares) scene as the production and trade region is also indicated. We must examine whether and to what extent opium was interesting for other areas than Malabar in this century.

More specifically: is opium also to be seen as one of the major links between Mughal India and the outside world? That world was dominated to a considerable extent by violent Western intruders, with the Dutch becoming much more important than the Portuguese or English and French. The Portuguese appeared on the scene almost at the same time as the Mughals. The dynasty of these important rulers was founded by Babur after entering Delhi in $15^{26}$.

8 Idem, p. 115. An aurung is 'a place where goods are manufactured, a depôt for such goods.' (Hobson-Jobson).

9 Idem, p. 155 is not as explicit, but points clearly to this constellation. 


\section{The Dutch Connection}

The Dutch arrived in Bengal nearly a century later at Hugli on the mouth of the Ganges. They were not yet interested in opium but sought rice, sugar, saltpeter and slaves. In the view of one of the first GovernorGenerals, Jan P. Coen, slaves were needed as willing labor in the Dutch colonies in the East Indies. Time and again he urged buying as many slaves as possible. In a letter to Commander Van den Broecke, for instance, he asked (8 May 1622):

Any number of slaves, particularly young people, could be sent to Batavia. Even if this number was 100,00o, the Dutch territories were extensive and productive enough to support them adequately. ${ }^{10}$

In practice, Coen never received such numbers, only about 30-80 slaves from Coromandel or Surat in particular. Soon these requests were not repeated. Indeed, a wide gap existed between what was ordered and what was ultimately delivered, as we will see below for opium also. It proved, however, that the Dutch wanted to be sedentary slave holders in their new East-Indies settlements and not only slave traders. ${ }^{11}$ The situation was no different with the establishment of colonies in the West Indies (Surinam, Dutch Antilles).

Regarding the Mughal realm, however, Coen and his successors never intended to establish colonies like the French or English did (except Ceylon ${ }^{12}$ ), but only to establish trading strongholds in or outside existing settlements. Coen was not very impressed by the profitability of the Bengal region within the framework of his inter-Asian trade network. Later, VOC Batavia judged the cost of the Malabar trade in the period 1663-1702 as too high relative to the profits. This must be taken with a large grain of salt because the Dutch were accustomed to gross profits

10 O. Prakash (1984), p. 203 and passim.

11 Scholars do not realize the serious differences in theory and practice between the two positions. I discussed them in an analysis of the different positions of the ancient Greeks and Romans: the former were the traders, indifferent to the fate of their "cargo" and the latter the holders, who were establishing their own model society by eradicating an indigenous one by means of a slave labor-force from elsewhere. All Western settlers in history tried to establish societies in the latter way from the Romans to the Portuguese and Spaniards to the Zionists in Palestine. See H. Derks (1986), p. $288 \mathrm{ff}$.

12 Its opium history must have been a strange one, because C. Uragoda mentions the Portuguese as masters of Ceylon once, jumps over 150 years of Dutch rule and starts with the English rule from 1815-1915. Before the British introduced opium on the island (see Appendix 1), opium was apparently only used in Ayurvedic medicine. 
often exceeding 1,000 percent, at least in their spice trade. But some local VOC officials blamed the building of extensive fortifications and the payment of high salaries instead of attacking the endemic corruption of Dutch officials. ${ }^{13}$

This kind of complaint soon changed in the typical inter-Asian commodity chains. First thanks to the experience that the Indian merchants were at least as clever as the intruders: spices imported by the VOC on the Indian east coast as cheaply as possible in order to create a better trade position for opium were transported overland by the Indian merchants to the west coast. In Surat the strongest competition came from the Indian merchants with their own VOC spices! ${ }^{14}$ The other side of the trade issue showed that in the 1630 satavia discovered considerable amounts of inexpensive raw silk in north-east India. It connected this silk trade to Japanese customers, and around $165^{\circ}$ silk was probably the single most important cargo shipped to Japan.

This Japanese trade was highly advantageous for the VOC: Japanese silver was exchanged for Chinese gold in Formosa (Taiwan); this gold could then be invested profitably in textiles on the Coromandel coast. Prakash continues with:

Due to the importance the Company attached to this trade, its employees were not allowed to engage in it on their individual account. That, however, did not prevent them from doing so on a fairly large scale on a clandestine basis. Indeed, in a high-value, low-bulk item such as opium which was ideal for contraband trade, the volume of the clandestine trade was often as large as that on the Company's own account. ${ }^{15}$

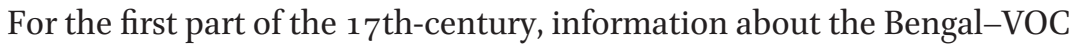
relationship is still meager. ${ }^{16}$ In that period the level of opium trade of the

13 About this opium corruption see K. Ward, p. 88, 89. Kerala, p. lxxxv gives all the details of the receipts and expenditures over 38 years. If I give the additions $(7,211,890$ guilders versus 11,502,000), it reveals, indeed, a negative balance of about 4.3 million guilders, which is a very large loss in those times. However, this is only a small part of the story: the huge profits made with pepper in Europe are not considered, and we further know almost nothing of the "value of the costs": in this case opium is bought in north-east India for an unknown price and used as means of exchange. Apart from this, Cochin is largely used as a refreshment station for ships and crews on the long route from Batavia to Amsterdam and that only adds costs!

14 F. Pelsaert, p. 54, 55.

15 O. Prakash in: E. Locher-Scholten and P. Rietbergen (ed.), p. 185.

16 In the Dutch "official" VOC historiography like F. Gaastra (1991) almost nothing is mentioned about this whole constellation. But the more interesting H. Furber, p. 258, 259 mentions several figures on the opium trade between 1613 until the beginning of the 18 thcentury which are seldom right or presented in a systematic way. Half a sentence refers to 
Dutch was also negligible. As shown, this changed in an explosive way after the relative defeat of the Portuguese. But this concerned, first, the quantity in one region.

In the second part of the century, the Dutch exported Bengal opium not only to the Malabar coast, but also to Southeast Asia (Malacca, Manila, Arakan or the East Indies archipelago), Ceylon, Maldive Islands, Gujarat (Surat, Cambay) and the Persian Gulf/Red Sea (Bandar Abbas, Hormuz or Jeddah). ${ }^{17}$ Bengal's opium figured in the inter-Asian trade as the VOC's second-best product after raw silk. This leads to a new characteristic of the Dutch opium trade: after 1660 it became not only a mass product for a specific location like the Malabar coast, it was spread over the East in a rather short period. Did it remain a mass product for other areas as well?

The following interesting table shows several aspects, primarily the sharp increase in the quantity of the opium trade for the archipelago. As such, the answer to the question is affirmative.

Next, a certain pattern is found: until 1667 there was a negligible amount of opium traffic apparently everywhere, after which it increased very quickly. In the last ten years 43 times more was officially exported to the archipelago than in the first ten years.

Sinha writes:

From the beginning the Dutch took the lead in the opium export trade from Hugli, and ... the Dutch succeeded in retaining their lead in this item ... Before Plassey the French and the English together did not export even half the quantity of opium which the Dutch exported. ${ }^{18}$

After the Battle of Plassey, in the period 1765-1775, the English conquered Bihar and Benares, including Patna, the main production area of opium. If we may believe Raynal, as quoted above the chapter, about half a million kilo (ca. 3000 chests $\mathrm{x} 300 \mathrm{lbs}$ ) was exported annually from Bengal around 1770 . This is not a bad estimate.

some Malabar relationship, etc. Three statements of Furber are certainly true: First, 'there is no evidence for extensive use of opium in the Malay archipelago in the sixteenth-century'. Second: 'Opium was the chief source of corruption in the Dutch company's service in the last half of the seventeenth-century ... private fortunes of hundreds of thousands of guilders were made ... the company had been defrauded of 3,800,000 guilders.' For that time unbelievable amounts of money and at present only comparable with fortunes of billions of guilders. Third: what the Dutch did with opium in Bengal and the East Indies 'laid the foundation for its [EIC's] monopoly of Bihar opium after the conquest of Bengal ... enormous profits for the so-called "opium contractors" among the company servants, who supplied the country traders.'

17 O. Prakash (1985), p. 28.

18 Quoted in C.Trocki (1999a), p. 46. 
Table 10. Bengal Opium Exported to the East Indies Archipelago, 1659-1718 (selected years; in Dutch pounds) $)^{19}$

\begin{tabular}{lcr}
\hline Year & Quantity Ordered & Quantity Exported \\
\hline 1659 & N.A. & 1360 \\
1663 & N.A. & - \\
1667 & $2000-3000$ & 2346 \\
1671 & $12000-15000$ & 5600 \\
1675 & 25000 & 26643 \\
1679 & N.A. & 28450 \\
1683 & N.A. & 33216 \\
1687 & N.A. & 43229 \\
1691 & 87000 & 87000 \\
1695 & 58000 & 88305 \\
1699 & 145000 & 69020 \\
1703 & $87000-145000$ & 120580 \\
1707 & $145000-174000$ & 39005 \\
1711 & $145000-174000$ & 116000 \\
1715 & $145000-174000$ & 159935 \\
Total 1659-1669: ca. 27 726 & & \\
Total 1708-1718: 1 197 845 & & \\
TOTAL 1659-1718: 3614001 & & \\
\hline
\end{tabular}

At that time the Dutch were still the largest opium customer-dealer. They increased this trade in the 18th-century again about 10 times from 1718 onwards. Or: for the whole of the 18th-century, on average 112 ,ooo pounds of raw opium were exported each year from Bengal and apparently also imported in Batavia, which comes to the unbelievable amount

19 Quoted from O. Prakash (1985), p. 150-151. The totals are the result of all the figures given in the period. D. Duco, p. 41 and 241 note 117, gives different data. J. Richards (1981), p. 61, mentions quite different figures also based on a forthcoming publication (unknown to me) of Prakash: for 'the late 1670s' he mentions an export of ' 35 Dutch tons' $(=35,000$ kilo) a level which is reached twenty years later. For the early years of the 18th-century, $5^{8}$ tons is given, whereas in 1715 for example about 80 tons are exported. E. Vanvugt (1988), p. $24 \mathrm{ff}$. has also different and sometimes wrong figures. It is senseless to discuss them here. The trend is everywhere the same, although the most recent (E. Jacobs, p. $128 \mathrm{ff}$., a Gaastra dissertation) has completely wrong figures. This is unbelievable since she directly referred to the studies of Prakash, Baud and Vanvugt (Idem, p. 400 note 63). In a following note 65, Jacobs refers to an important document, Adriaan van Ommen's memorandum of 1688, suggesting that all authors mentioned above used this highly suspicious document. This remains a wild allegation when it is not mentioned what was wrong with Van Ommen's document. 
of 11 million pounds in a century. ${ }^{20}$ Compared to this, the English were minor players in the opium trade of this period.

Now, several pressing questions require an answer, if possible.

\section{Mughal Production and Consumption}

An obvious question is how opium functioned in the enormous Mughal empire and society? Although there is much support for the thesis of the Dutch "original sin", it would be good to know more about the popularity of opium among the indigenous peoples in the pre-Dutch period. That is not an easy problem, about which I only can make some reasonable guesses.

At the moment scholars do not go beyond the statements of Chatterjee. His excellent study describes how Patna opium drew non-European buyers from all over in the beginning of the 17th-century. He adds: 'The participation of the European companies in this export trade expanded it considerably. But business in ... opium was not a new phenomenon. The additional demand of the European companies merely enlarged its scale.'21 However, a note is appended to this argument:

The available sources make it impossible to calculate the extent to which the demand of the European companies enlarged this export trade. But the descriptions of Patna's export market, especially in EFI, volume 1, confirm the view that the presence of the European companies increased the competition among merchants for the purchase of Patna's traditional export commodities. $^{22}$

This is not very helpful. The reference to EFI, William Foster's thirteenvolume document collection, The English factories in India (1906-1927), is too British, covers in fact only forty years (ca. 1620-1668) of a period in which the British were still a minor factor in all trade in the realm. There were plans enough to invest in various things, but there is no proof that they did so. Only the Portuguese and Dutch trade is relevant in this framework, and the former were simply not active in the opium trade deserving of this name. The English had no market network at the time in which opium could be sold profitably. And, as shown above, the Dutch really

20 D. Duco, p. 41. Below we have to confront these data with our analysis of the situation in the "Dutch" East Indies.

21 Idem, p. 27.

22 Idem, note 70. 
started with a relevant opium trade only after 1660 . So, we have to walk on a different path to get to the beginning of an answer about opium production, consumption or trade.

The image of an opium-stricken Mughal India is nurtured in particular by the much quoted François Bernier (1625-1688). Take, for instance, David Owen who writes:

In official circles of Moghul India the poppy and its derivative seem to have had their uses. The emperors themselves discovered in the seeds a subtle means of dealing with political enemies, "whose heads the monarch is deterred by prudential reasons from taking off”. An infusion of poppy seeds in water, explains Bernier, "is brought to them early in the morning, and they are not permitted to eat until it be swallowed. This drink emaciates the wretched victims; who lose their strength by slow degrees, become torpid and at length die. ${ }^{23}$

Fancy stories like this, uncritically publicized by the famous Report of the Royal Commission on Opium (1894-95), functioned largely to portray a terrible Asian opium past in which honest Westerners played their legal opium profit game to the benefit of mankind. First, opium seeds used in this way are fully innocent, even if they could be dissolved in water. Owen did not check the information from the Royal Commission. Bernier did not wrote about seeds, but about the poust which

is nothing but poppy-heads crushed, and allowed to soak for a night in water. This is the potion generally given to Princes confined in the fortress of Goaleor, whose heads the Monarch is deterred by prudential reasons from taking off. A large cup of this beverage is brought to them early in the morning ...[etc.]... who lose their strength and intellect by slow degrees, become torpid and senseless, and at length die. ${ }^{24}$

Bernier provides this explanation in a story in which a captured prince was brought before Aurungzeb, who released the handsome man. This prince proposed to Aurungzeb 'that if it were intended to give him the poust to drink, he begged he might be immediately put to death'. All this, however, did not happen this time. The method was apparently known and feared among the few captured Mughal princes!

Still, it is not very realistic to believe that poppy heads do have these effects. ${ }^{25}$ We do not intend to provide a more realistic opium image of Mughal India here, but the following could form a start.

\footnotetext{
23 D. Owen, p. 3 ff.

24 F. Bernier, p. 106, 107.

25 See, for instance, the long quote in the next chapter of the VOC historian Pieter van
} 
In particular, the Muslim reign of Akbar (1556-1605) was a golden age. A standardized tax system was introduced; there came general prosperity in agriculture and a buoyant trade everywhere. His successors expanded the empire at the cost of the Hindu confederacy of Maratha. It reached its largest extent around 1700 (not the Malabar coast) under the reign of Aurangzeb (1658-1707). European travelers reported about the Mughal court of the latter showed an ostentation without parallel among European courts. ${ }^{26}$

Aurangzeb's orders prohibiting the use and sale of opium may have not been very effective. ${ }^{27}$ It proved, however, that there was some opium problem in India. Did it exist only at the extensive Mughal courts? Or did it concern political and economic competitors in trade or production? Is it possible to define this specific Mughal opium problem?

The first aspect is a purely economic one. The Portuguese, Dutch and other foreigners poured in much gold and silver to pay for the local products or as bribes for the many kings. This affected remote inland regions like the Deccan as well as the coast. It is even claimed that the expansion of the Mughal empire depended on this influx of gold and silver. After about 1660 Bengal was a prominent 'silver-consuming region'. Since the Dutch opium trade was pivotal to the foreign presence, it meant that the splendid culture of the Mughals was a product of a narco-military regime. In this case Aurangzeb's opium prohibition was theoretically directed to the very source of his own wealth, which is not very understandable.

But quite a different conclusion could be drawn. Because the opium purchased on a large scale with silver and gold in Bengal was in turn used by the Dutch in a barter exchange for pepper, it is possible that Aurangzeb's prohibition concerned this barter exchange. It also undermined his gold and silver income. This remarkable example of inter-Asian trade, this time between the East (Bengal) and West (Malabar) Indian coast, proved that his power could not be extended to the latter.

Another perspective concerns the internal organization of the Mughal empire. It can be said that the strong centralized administration of the Mughals in the North directed the economy in particular ways. An im-

\footnotetext{
Dam with quite different information about poppy heads and that of the VOC physician, Engelbert Kaempfer, about an opium mixture.

${ }^{26}$ See for the luxury of the court, the chapter by Tapan Raychaudhuri in: T. Raychaudhuri, I. Habib (ed.), p. 180 ff.

27 S. P. Sangar, p. 204. This author discusses opium, post, bhang, dhatūra and tobacco with many quotations from the Mughal period. See also D. Hall, p. 203.
} 
portant factor was that the Mughals had a fairly sophisticated monetary system. ${ }^{28}$ Together it formed the backbone of the classical oikoidal society (not the modern), in which the centralized political-military entity is not yet combined with economic capitalist monopolies: the powerful Indian opium producers-merchants were private interests, and that is, in fact, even the case with the coin minters. ${ }^{29}$

The modern capitalist concepts and violent practices backed by some Western oikoidal state powers were introduced by the Western invaders. In the 17th-century they could upset but not yet revolutionize the Indian economy and society, as happened from about 1760 onwards. Thus, certainly until this date, people like Aurangzeb were confronted with powerful merchant families in Surat, Agra, Delhi or Benares, Coromandel or Bengal.

Chaudhuri and others gave them a name and described their deeds, including Indians with 'the sinister reputation of Omichund' or Jews, Greeks and Armenians. ${ }^{30}$ The latter had already operated for centuries in India and continued troubling the activities of the EIC in the 18th-century. They all had a major stake in the opium trade as did, for instance, the Parsees and Jews in the 19th-century. In short: Aurangzeb's prohibition could have been directed at limiting the economic power of these merchants.

A third view is possible on this remarkable rule which hits at one of the most serious activities of important private interests. Under Aurangzeb's regime the struggle was still raging between the Portuguese and Dutch for supremacy. Since opium was a typically Dutch affair, his prohibition could be a form of taking sides in this struggle. His practices were followed by Muslim scholars active in the Southeast Asian peninsula and archipelago. Hall's description probably illustrates the background of Aurangzeb's prohibition as well:

The Muslim scholars ... gave impetus to the political expansion of Islam and also strove to promote a sense of unity among the Muslim communities ... in opposing the advance of Portuguese and, later, Dutch power ... it showed

28 K. Chaudhuri (1978), chapter 8 and, in particular, p. $174 \mathrm{ff}$.

29 The oikos concept is also used by J. van Leur, p. 53-6o, but in an ahistorical and uncritical Weberian way. See H. Derks (1986), passim or H. Derks (2008). A more to the point approach can be reached by a "flexibilization" of the classical Marxist positions, starting with Marx's own interpretation of the opium use in India. An interesting article is I. Habib, passim. See for the military side also S. Halperin, p. 136-150.

30 K. Chaudhuri (1978), p. $146 \mathrm{ff}$. and the contribution of Sushil Chaudhury about the Armenian merchants in: I. Baghdiantz McCabe et al (ed.), p. 51-73. 


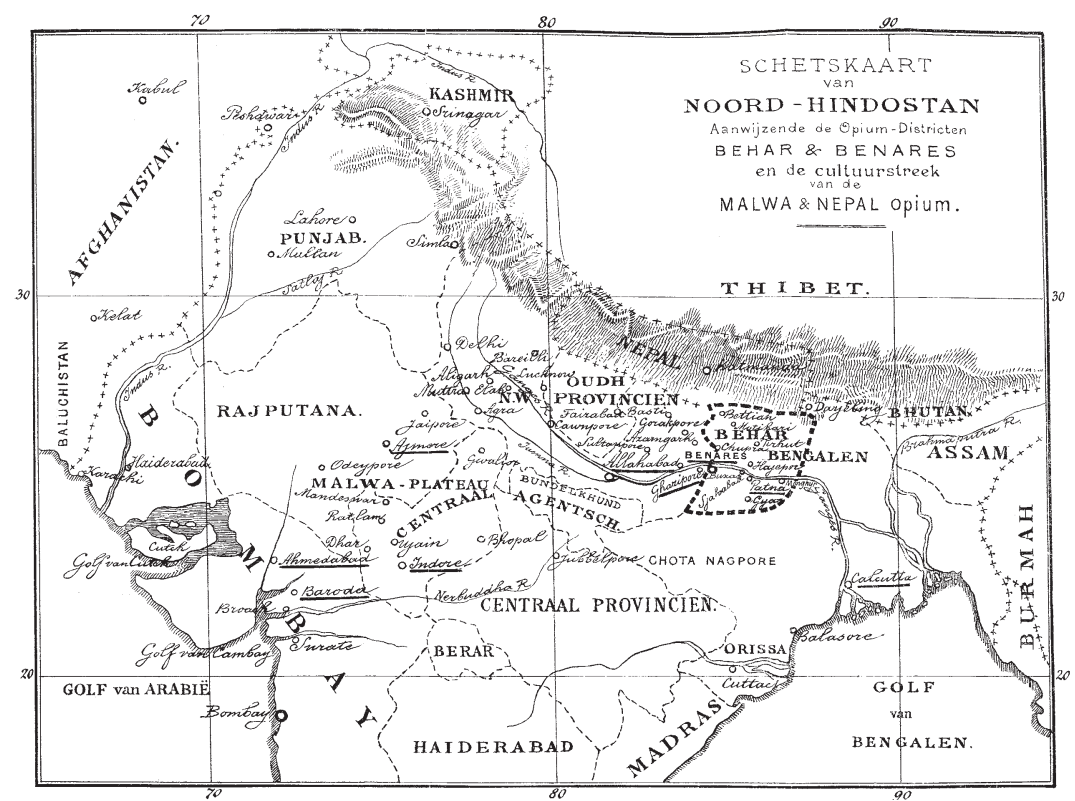

Map 4. Sketch-map of North Hindostan showing the Opium districts Behar and Benares and the landscapes of the Malwa and Nepal Opium Cultures, ca. 1880

Source: J. Wiselius, 1886 , appendix.

itself in punishments for using tobacco and opium similar to those established at the same time by Aurangzeb in Mughal India, in anti-European propaganda ... in stimulating an interest in Mecca and the pilgrimage, and in spreading a knowledge of Arabic literary works ...31

In this case, however, Aurangzeb gambled wrongly on the losing party. His own defeat could be seen as a consequence of this choice.

The above considerations concern the production and trade relations of the opium business in Mughal India. ${ }^{32}$ Usually (and erroneously) an opium problem is only defined as a matter of spreading addiction. What about this side of the problem?

It is well known that in Mughal India, the consumption of opium (afyūn or afim) and many other intoxicants (bhang, charas, ma'jun, ganja or hashish) was widespread among the court, as several authors have

31 D. Hall, p. 203.

32 For a general assessment of the VOC and Mughal India relationship see the article by O. Prakash in: E. Locher-Scholten and P. Rietbergen (ed.), p. 183-201. 
disclosed. ${ }^{33}$ A source that uncovers this side is François Pelsaert (1595?1630). He was a clever and controversial VOC merchant who lived for seven years in the center of Mughal India, Agra. In 1627 he wrote an extensive historical treatise and an intelligence report for VOC Batavia about the previous century of the Mughal society and political developments, the kinds of products, about coins and measures, or the position of the rich and poor. ${ }^{34}$

An often repeated remark in these writings sounds both reasonable and uncritical in the mouth of a representative of a violent Western nation:

[The fruitfulness of the land] should be much more abundant but the peasants have been treated so cruelly and without any mercy. The villages, which are not able to pay the full rent (because of limited harvests), are abandoned; wives and children are sold under the pretext that they are rebellious. ... So lands remain empty and uncultivated, reclaimed by the jungle ... ${ }^{35}$

Pelsaert often comments on the subject of opium. At the beginning of his chronicle, he tells the anecdote that a king 'who always consumed much opium' fell off the forty steps of a staircase and died in $1556 .{ }^{36}$ Another story reveals how a princely prisoner-addict is personally given his stuff by the king. ${ }^{37}$

The trade of Agra is described in detail. The exports mentioned are amphioen (opium), salt or painted cloth. ${ }^{38}$ Alas, no quantities are given. About the present Punjab (Pakistan), he describes how much sugar and 'much amphioen' is grown around the city of Multan, which is transported

33 By a.o. K. Lal; S. Mukherjee; S. Sangar. As I write this, an announcement is circulating of the 21.European Conference on Modern South Asian Studies (26-29.07.2010) in Germany. The abstract of a paper of Nirmal Kumar ('The creation of morals: alcohol and opium consumption among the Mughal elite') is published as well.

34 He was controversial because he speculated privately in indigo or in diamonds with the money of the VOC; sold young female slaves in particular or had a rather dangerous affair with the wife of an important Mughal official, who died in his house under strange circumstances, etc. In addition, the adventurer Pelsaert is a clever reporter about the history and society of the Mughals.

35 F. Pelsaert, p. 295. His description of the sharp antagonism between rich and poor is also rigorous, p. $308 \mathrm{ff}$. Although he had to come up with the usual remarks about the nonChristian pagans (to flatter his own VOC Directors), he is clearly sympathetic to Islam, while Hinduism remains Greek to him.

\footnotetext{
36 Idem, p. 72, 73 .

37 Idem, p. 112.

38 Idem, p. 254.
} 
to Agra via Lahore ${ }^{39}$; Srinagar is also an opium-consuming city. ${ }^{40}$ A general remark about the rich-poor antagonism in Mughal society is that the servants are apparently big opium consumers. After listing their many kinds of labor — a different servant for every task — he writes:

But they eat constantly much hashish or amphioen, so that they do not feel the continuous labor or fatigue. Therefore, they walk around rather dizzy, so that if somebody asks them something they only answer after being pressed to do so. ${ }^{41}$

It is difficult to understand how somebody can become tired of helping his master onto his horse a few times a day, or ringing a bell if his master has to cross the street, cleaning his master's chair, etc. According to Pelsaert, the reason for the opium consumption is exhaustion: he thinks that a servant walks ' 25 to 30 coss' every day, where one coss equals 5 kilometers! These servants earn 3 to 4 rupees in 40 days. Can they afford opium if they do not have Papaver somniferum somehow at their disposal? It is difficult to believe that these servants could be opium addicts. Who then are the opium consumers?

The author writes extensively about the position of the well-to-do women and their wealth 'pressed from the sweat of the poor'. These women must always be prepared to spoil their husbands with all kinds of aphrodisiacs, including opium. Apparently, they themselves constantly drink wine. Pelsaert reports about other representatives of the elite, for instance, that the Rajputs were excellent soldiers 'because the quantity of opium they ate excited them'. ${ }^{42}$ This reminds me of the later report of Willem Schouten about the aristocratic nairos of the Malabar coast. The Hindu Rajputs or Rajas were also the subject of Bernier's travel report, which has nearly the same information as Schouten. Bernier:

They might be said to form a species of Gentile nobility ... From an early age they are accustomed to the use of opium, and I have sometimes been astonished to see the large quantity they swallow. On the day of battle they never fail to double the dose, and this drug so animates, or rather inebriates them, that they rush into the thickest of the combat insensible of danger. ${ }^{43}$

\footnotetext{
39 Idem, p. 278.

40 Idem, p. $283,284$.

41 Idem, p. 310.

42 Quoted by S. P. Sangar, p. 203.

43 F. Bernier, p. 39, 40.
} 
Are other soldiers good opium consumers as well, which is not an unimportant question since a Mughal army is quite large? Pelsaert comes up with an extensive calculation of what Akbar left behind as a treasure in gold, silver, books (24,00o 'written by great authors'), canons, other weapons $(8,575,971)$ and about two million horses. ${ }^{44}$ More recent calculations support this picture more or less. Around 1650 there were 185 , ooo horsemen, 7,00o cavalrymen and matchlock-bearers, 40,00o artillery men as well as 40,00o infantry. To this should be added about 4.7 million retainers, including 300,000 horsemen in the employ of the zamindärs. Altogether this is close to five million warriors. However, the total of nonmilitary personnel in army service and

the nobles and the imperial establishment and the families of all the people thus employed ... has been estimated at some 26 million, a remarkably large figure for a population estimated at a mere 100 million ... ${ }^{45}$

The bulk of this 26 million is maintained at a level of bare subsistence, but the five million soldiers mentioned were paid at rates well above that level. If we suppose that the latter are opium clients, is it possible to compare this potential consumption to the production?

It is rather difficult. Bernier goes into extensive detail on the Bengal trade in cotton cloth and silks

in particular of the Hollanders ... The Dutch have sometimes seven or eight hundred natives employed in their silk factory at Kassem-Bazar ... Bengale is also the principal emporium for salpetre ... Lastly, it is from this fruitful kingdom, that the best lac, opium, wax, civet, long pepper, and various drugs are obtained ... ${ }^{46}$

This must concern information about the early 1660 . It does not suggest that opium is already a booming product in foreign trade (see table above).

44 B. Narain, S. R. Sharma (ed.), p. 33-35. The calculations are not very good: 1,068,248 horses must be $1,962,547$; their 7,281 commanders should be 7,312 , etc. The same calculations, including the errors, are also in F. Pelsaert, p. 116-121. See for similar calculations Idem, p. $246 \mathrm{ff}$. about the aristocrats of Agra. In addition, there are numerous wrong numbers in one or the other text. Narain and Sharma reproduce only Pelsaert's chronicle and not the much more interesting Remonstrantie, in my view at least, the "intelligence" report for the VOC Directors. But their edition is much more critical than the one of the Dutch editors Kolff and Van Santen.

45 See the contribution of Tapan Raychaudhuri in: T. Raychaudhuri, I. Habib (ed.), p. 179 .

46 F. Bernier, p. 439, 440. 
About twenty years later a more detailed assessment is possible. A VOC account of the year 1688 states that in Bihar the annual output of opium in a normal year is about 8,700 maunds, which is about 600,00o Dutch pounds. This account provides the following clue, namely

that of the total output only about 0.6 percent was consumed within Bihar. Another about 10 to 12 percent was sent to other parts of the Bengal region. The exports to Agra and Allahabad reportedly accounted for yet another 34.5 to 46 percent of the total output. The remaining 41 to 55 percent was exported to other national and international markets. The average amount procured annually by the Dutch Company around this time was approximately 1, ooo maunds [68,ooo Dutch pounds], accounting for about 11.5 percent of the total output. This, of course, does not take into account the illegal private trade carried on by the Company's servants in this item, which often matched the trade carried on by the Company. ${ }^{47}$

A first conclusion: in this year 1688 the Dutch officially exported to the East Indies 758.82 maunds (51,6oo pounds) and to Malabar 48.24 maunds $(3,280$ pounds $)$, which is a bit more than 800 maunds in total. ${ }^{48}$ Therefore, about 200 maunds are exported to the other destinations mentioned. Let's suppose that the VOC servants privately traded the same amount, then one can say that the Dutch in this specific year together distributed about 1,60o maunds, and about 7,00o maunds remained somehow in northern India.

What does this mean? What kind of proportion did this consumption take? A preliminary calculation runs as follows, based on the reasoning that Agra and Allahabad were the most important destinations of the opium export. At that time Agra was a big city of 500,000 inhabitants and Allahabad of ca. 200,000.

Together they consumed, therefore, about 3,500 maunds or, on average, 0.01 maund per person in a year. This equals about 340 grams or less than 1 gram a day: nobody can become an addict from this! If one should say: opium consumption was only something for the elite at that time (say, about $10 \%$ of the population of these cities) a consumption of 3,500 maunds results in about 0.05 maunds per person per year, or 4.5-5 grams per person per day. There is a good chance of becoming an addict or at least dependent on opium with this daily quantity! Certainly, if it con-

47 O. Prakash (1985), p. 58. On p. 150 for the year $1688-89$ Prakash mentions an export of only 51,6oo pounds and a quantity ordered of 97,00o pounds. One Bengal maund = 68 Dutch pounds $=75$ lbs avoirdupoids $=34.05$ kilogram.

48 O. Prakash (1999), table 6.2 p. $15^{0}$ and Idem (1985), p. 171 
cerns opium of the Patna quality (and not of the Malwa) at the end of the 18th-century, world-famous according to the Frenchman Raynal.

A second calculation focuses on the five million well-paid members of the Mughal courts and army. If they consumed the 7000 maunds of the remaining Bengal production, the consumption per person per year should be about 50 gram, an entirely negligible quantity.

There are historians (Sinha) who deny that the cultivation of opium was encouraged in Mughal India. ${ }^{49}$ Probably not by the emperors and the courts, but certainly by many merchants-producers. The only conclusion I can draw from the above is that there must have been a reasonable consumption of opium among what could be called the elite. This, however, did not lead to a substantial addiction problem. In all probability, Aurangzeb's prohibition must concern not the consumption or even a moral point of view, but the production and trade relations.

Of course, one knew about the bad effects of excessive opium consumption, resulting in serious personal problems. Several Asian governments warned against opium or prohibited its use, but-for the time being-we should judge these actions as now analyzed for the Mughal empire: not from the consumption side.

One thing is clear: in Mughal India there were no negative moral values associated with aphrodisiacs, including opium. Kumar is right to combine this moral understanding with the openness about sexuality in the whole of Mughal society. West Europeans, mainly missionaries, Protestant travelers and British occupiers demonstrated a totally negative Christian perception of sex or lust with, furthermore, not the least understanding of the common use of numerous herbs. The Portuguese were more flexible in both respects. Kumar even pointed to the 'criminalization of herbs and medical preparations' as a consequence of British rule.

Another thing is clear as well: it was the Dutch merchants who pushed this Bengal opium production, and after the English took over power in India, they remained the main customer until the British transferred this trade to the Chinese empire. The target of the Dutch was not India but the East Indies archipelago. That will be the setting of the next chapters: they deal with those who brought the real Opium Problem into the world, which deserve detailed explanations.

49 C.Trocki (1999a), p. 45. 